\title{
Livelihood Security of Women Agricultural Labourers in Erode District of Tamilnadu
}

\author{
G. Ramesh Pandi, B. Inayath Ahamed, A. Saravanan
}

\begin{abstract}
Aim: The main aims of the study is to identify the socio-economic characteristics of women agricultural labourer, to identify the determinants linked with economic, food, health, edification and empowerment as dissimilar domains of livelihood security of women agricultural labourers and to estimate the determinants of livelihood security of women agricultural labourers in Erode District of Tamil Nadu. Methods/Statistical analysis: The research has curbed in to a sample of 140 women agricultural workers households were selected from four villages of Bhavani taluk of Erode District in Tamil Nadu. A simple percentage analysis has been employed to identify the socio-economic characteristics and Multiple Regression equation method has fitted to the data to explore the effects of the explanatory variables on livelihood security of women agricultural labourers. Findings: Out of the 140 sample women agricultural labour households selected for the study, vast majority of the households registered as nuclear type of families; 52.86 percent with $2-4$ members; 62.14 percent of the women agricultural workers were in the age cluster of 30 - 60 years; 33.57 percent of the respondents had education at secondary level; 33.57 percent labourers income falls in the income group of Rs.25000-Rs.50000/-,45.00 percent of the households selected for the study were with the asset group valued below Rs.2.5 lakhs. There was positive relationship of the explanatory variables with composite livelihood security index of agricultural women workers. Conclusions: Government intervention through legislation, planning and implementation must be stepped up to provide greater opportunity for the sustainable development of women livelihood security at all levels, so that the discriminatory practices of women and the gender related issues against women would be addressed.
\end{abstract}

Keywords: Livelihood security, women, Agricultural workers,

\section{INTRODUCTION}

Women make up half of the world's population and one-third of the labour force, but get only one-tenth of world revenue and possess less than one percent of world assets. The process of economic development has caused several key changes in the structure of developing countries, including changes in the distribution of labour in various types of economic activity. The most important changes concern the involvement of women in economic actions. The main occupation of rural women is agriculture and related activities, which provide about three-quarters of the labour force needed for agricultural work. The prosperity and growth of not only the nation, but also the rest of the population

Revised Manuscript Received on December 09, 2019.

G. Ramesh Pandi, Associate Professor\& Head, Department of Commerce, Kalasalingam Academy of Research and Education, Krishnankoil, Virudhunagar District, Tamilnadu. Email: g.ramesh.jith@gmail.com

B.Inayath Ahamed, Assistant Professor, Department of Business Administration, Kalasalingam Academy of Research and Eductaion, Krishnankoil Email: g.ramesh.jith@ gmail.com

A.Saravanan Assistant Professor, Department of Economics, J.K.K.Nataraja College of Arts \& Science, Komarapalayam-638183, Namakkal District, Tamil Nadu. Email: saravananchamp@ gmail.com Livelihood Security Index

depends on the status and development of its female population.

Women are the basis of the rural economy of India. Women engage in various livelihood activities, and the majority of rural women depend on agriculture, which is the main informal sector in India. Many of these landless labour resources have a lower socioeconomic status. The role and status of women are changing in the process of agrarian transformation due to growing technology. The impact of new technologies has benefited only rich farmers, not poor agricultural labor, and as a result, the gap between poor and rich has widened further, and agricultural labor has remained far behind.

\section{REVIEW OF THE LITERATURE}

Ganesh Kumar et al (2009) indicated that tsunamis devastated households, permanent crops, agricultural resources like seeds, feed and tools, livestock and poultry, their sheds, fish ponds, etc., on the elementary security of the livelihoods of citizens in Andaman. Rehabilitation measures taken by the government and NGOs enhanced their livelihoods, considerably vitalizing agriculture in the following years and developing employment openings in the different regions of agriculture and non-agricultural actions. Sanzidur Rahman and Shaheen Akter (2010) showed that five security areas selected, like economics, food, health, education or edification and empowerment, and indices were calculated based on a number of components. Studies have shown that economic security is the dominant component of the general livelihood, followed by food. Regardless of regional differences in opportunities, people in settlements look equally insecure. Marc Lindenberg (2012) concluded that the study seriously considers Jimmy Carter's idea of progress in the new millennium. Household livelihood approaches will help us directly focus on the needs and basic rights of a growing number of people who will live in absolute poverty in the coming decades. Dhanasree et al (2013) showed that a holistic approach is desirable for the success of tribal development and for a model of sustainable livelihoods, and a solid resource base is a necessary condition. It is most desirable to extend sustainable socioeconomic status, empower women, improve health care, programs aimed at improving nutrition, provide transportation and communication for tribal households. Yishak Gecho et al (2014)indicates that the polynomial logit model is used to study the factors influencing the choice of household livelihoods. In this regard, a total of 19 explanatory variables were included in the empirical model, of which 11 variables, such as gender, education, farm size,

livestock ownership, participation in social leadership, annual cash income, fertilizer use, improved seed utilization, age and training, defined farmer's livelihood strategies. 


\section{PROBLEMS OF THE STUDY}

There are significant differences in the degree of mobility, degree of control when making decisions, the state of livelihood and values of women in communities, regions and countries. Women's contribution to agriculture and domestic activities is quite high, but not enough attention is paid to the various visible and invisible problems faced by women in rural areas. The heavy workload of women in rural areas has recently been aggravated by the considerable migration of men to and out of cities in search of better income-generating opportunities. Other common problems of rural women are their limited access to social services, loans and the distribution of agricultural products, The literacy rate of the population is low, and they have little control over resources. In addition, progress in improving the socio-economic situation and the living conditions of women, especially in rural areas, was very slow, because their uniqueness has inherited many myths and taboos. Such socio-economic conditions require policies and programmes of action to improve women's access to scarce and valuable resources in their societies (in particular, to their livelihoods and economic resources), to facilitate disproportionate household duties, to eliminate the legal and response spectrum of households and the sexual aspects of their daily lives and raising public awareness through effective programs. There is an urgent need for a focused understanding of the situation of women and participation in livelihoods for both women and the family as a whole. Keeping the crux of the above problems of women in view, the present study entitled "Livelihood Security of Women Agricultural Labourers in Erode District of Tamilnadu"is an attempt in this direction.

\section{AIM OF THE STUDY}

The main aim of the study is to know the socio-economic characteristics of women agricultural labourers, the factors associated with economic, food, health, education and empowerment as different domains of livelihood security of women agricultural labourers and to estimate the determinants of livelihood security of women agricultural labourers in Erode District of Tamil Nadu.

\section{METHODOLOGY}

Erode district form the universe of study. The district has six taluks, Such as Anthiyur, Bhavani, Gobichettipalayam, Erode, Perundurai, and Sathyamangalam, of which Erode, Gobichettipalayam and SathyamangalamTaluks, of which Bhavani Taluk has selected for the study. The Purposive cum Multistage Random Sampling Technique was felt appropriate to choose villages and agricultural labourers respectively for the collection of data. For the purpose of data, 4 revenue villages were selected at random. A list of households in each revenue villages was obtained from the records available in the Village Administrative Office, of which 35 women agricultural labourers' households in each village (a total of 140 households) were selected at random.

For the objective evaluation of data relating to the various socio-economic characteristics of the study, statistical tools starting from simple tabular and percentage analysis to the multiple regression analyses were employed in the study. The Livelihood Security Index for each dimension viz., Economic Security Index (ECOSI), Food Security Index (FOOSI), Health Security Index (HEASI), Education Security Index (EDUSI) and Empowerment Index (EMPOI) were constructed by using the Human Development Reports (also adopted by Hahn et al. 2009) formulation on Human Development Index;

$$
\operatorname{zind}_{j}=\frac{X_{i j}-\operatorname{Min}\left(X_{i}\right)}{\operatorname{Max}\left(X_{i}\right)-\operatorname{Min}\left(X_{i}\right)}
$$

Where,

$z_{i n d}=$ A Standardized indicator $j$

$X_{i j}=$ Actual score value of the indicator

$\operatorname{Min}\left(X_{i}\right)=$ Minimum score value of the indicator

$\operatorname{Max}\left(X_{i}\right)=$ Maximum score value of the indicator

Once each indicator representing a particular livelihood security domain is standardized, then the appropriate household livelihood security index for the particular domain has created by averaging the standardized indicators:

$$
H L S_{j}=\frac{\sum_{j=1}^{J} \text { zind }_{j}}{J}
$$

Where

$$
\begin{aligned}
& \text { HLS }_{\mathrm{j}}=\text { Household Livelihood Security Index } \\
& J=\text { the number of indicators } \\
& \sum_{j=1}^{J} z_{i n d_{j}}=\text { sum of standardized indicator } j
\end{aligned}
$$

Once each HLS index is created, then the composite overall Livelihood Security (LS) index for the agricultural labourer household is created for each taluk level data by using the formula in equation;

$$
L S_{i}=\frac{\sum_{i=1}^{n} w_{i} H L S_{i}}{\sum_{i=1}^{n} w_{i}}
$$

Where, $w_{i}$ are the weights determined by the number of indicator employed to create each HLS index. Weights differed between households because of household level deviation in the number of indicators.

In order to estimate the determinants of livelihood security of women agricultural labourer in rural areas under the existing social structure in the district, a quantitative Multiple Regression Analysis of the following OLS method was used;

$$
Y=\alpha+\beta_{1} X_{1}+\beta_{2} X_{2}+\beta_{3} X_{3}+\ldots \ldots \ldots \ldots+\beta_{n} X_{n}+\varepsilon
$$

Where,

$$
\begin{aligned}
& Y=\text { composite overall Livelihood Security (LS) } \\
& \text { index } \\
& \alpha=\text { Intercept } \\
& X_{1}, X_{2}, \ldots X_{n}=\text { Independent variables }
\end{aligned}
$$

$\beta_{1 . . .} \beta_{n}=$ are the parameters to be estimated $\varepsilon=$ Random unobserved disturbance term, with the mean as zero and the variance as constant 


\section{RESULTS AND DISCUSSION}

A. Socio-Economic Characteristics of the Sample Households in Erode District

The important socio-economic characteristics identified for analysis in the study are number of male and female population, family type, family size, number of earners, number of dependent and dependent ratio, average age at respondent marriage, respondent age at present, difference between age at marriage and age at present, age group of the respondents, educational status of the respondent, occupational participation of the household heads, household income, household expenditure, assets, access to media and communication networks and political participation of the agricultural women in the rural areas of Erode district in Tamil Nadu and is presented in table-I.

\section{TABLE-I: SOCIO-ECONOMIC CHARACTERISTICS OF THE SELECTED SAMPLE HOUSEHOLDS IN BHAVANI TALUK}

\begin{tabular}{|c|c|c|c|}
\hline \multicolumn{2}{|r|}{ Variables } & $\begin{array}{c}\text { No. of } \\
\text { women } \\
\text { agricultur } \\
\text { al } \\
\text { labourers } \\
\end{array}$ & Percent \\
\hline \multirow[t]{2}{*}{ Family Type } & Nuclear & 111 & 79.29 \\
\hline & Joint & 29 & 20.71 \\
\hline \multirow[t]{4}{*}{ Family size } & Below 2 Members & 23 & 16.43 \\
\hline & 2 - 4 Members & 74 & 52.86 \\
\hline & 4 - 6 Members & 29 & 20.71 \\
\hline & Above 6 Members & 14 & 10.00 \\
\hline \multirow[t]{3}{*}{ Age Group } & Below 30 Years & 38 & 27.14 \\
\hline & $30-60$ Years & 87 & 62.14 \\
\hline & Above 60 Years & 15 & 10.71 \\
\hline \multirow[t]{4}{*}{$\begin{array}{l}\text { Educational } \\
\text { Status } \\
\end{array}$} & Illiterates & 48 & 34.29 \\
\hline & Primary Level & 29 & 20.71 \\
\hline & Secondary Level & 47 & 33.57 \\
\hline & $\begin{array}{l}\text { Higher Secondary and } \\
\text { Above }\end{array}$ & 16 & 11.43 \\
\hline \multirow[t]{5}{*}{$\begin{array}{l}\text { Annual } \\
\text { Income } \\
\text { group }\end{array}$} & Below Rs.25000 & 37 & 26.43 \\
\hline & Rs. 25000 - Rs. 50000 & 47 & 33.57 \\
\hline & Rs.50000- Rs. 75000 & 28 & 20.00 \\
\hline & $\begin{array}{l}\text { Rs. } 75000 \text { - Rs. } \\
100000\end{array}$ & 16 & 11.43 \\
\hline & Above Rs. 100000 & 12 & 8.57 \\
\hline \multirow[t]{3}{*}{$\begin{array}{l}\text { Monthly } \\
\text { Expenditure }\end{array}$} & Below Rs.4000 & 42 & 30.00 \\
\hline & Rs.4000 - Rs.8000 & 73 & 52.14 \\
\hline & Above Rs. 8000 & 25 & 17.86 \\
\hline \multirow[t]{6}{*}{$\begin{array}{l}\text { Asset } \\
\text { distribution }\end{array}$} & Below Rs.2.5 lakhs & 63 & 45.00 \\
\hline & Rs.2.5 - Rs.5.0 lakhs & 44 & 31.43 \\
\hline & Rs.5.0 - Rs.7.5 lakhs & 16 & 11.43 \\
\hline & Rs.7.5 - Rs.10.0 lakhs & 11 & 7.86 \\
\hline & Above Rs.10.0 lakhs & 6 & 4.29 \\
\hline & Total & 140 & 100.00 \\
\hline
\end{tabular}

Source: Primary Data

The socio-economic characteristics of the sample women agricultural labourer households selected for the study revealed that out of the 140 sample women agricultural labourer households selected for the study, vast majority of the households were registered as nuclear type of families. The family size of the selected sample women agricultural labourer households revealed that out of the 140 sample households selected for the study from Bhavani taluk, 16.43 percent of the households had family size of below 2 members, 52.86 percent were with 2-4 members, 20.71 percent were with 4-6 members and 10.00 percent were with family size of more than 6 members. Out of the 140 sample women agricultural labourer households selected for the study, 62.14 percent of the respondents were in the age group of $30-60$ years; while 27.14 percent were below the age of 30 years. From the point of view of the educational status of the respondents selected for the study, 33.57 percent of the respondents had education at secondary level; 20.71 percent and 11.43 percent had education at primary and higher secondary levels.

Out of the total sample women agricultural labourer households selected for the study, 26.43 percent of them were with the income group of below Rs.25000/- followed by 33.57 percent whose income falls in the income group of Rs.25000-Rs.50000/-, 20.00 percent of them were in the income group of Rs.50000-Rs.75000/-, 11.43 percent of them were in the income group of Rs.75000-Rs.100000/- and 8.57 percent were found in the income group of above Rs.100000/per annum. The asset distribution of the households showed that 45.00 percent of the households selected for the study were with the asset group valued below Rs.2.5 lakhs, 31.43 percent were recorded in the asset group worth of Rs.2.5 - 5.0 lakhs, 11.43 percent were in the asset group of Rs.5.0 - 7.5 lakhs,7.86 percent were in the asset group of Rs.7.5 - 10.0 lakhs and 4.29 percent were in the asset group of above Rs.10.0 lakhs.

\section{B. Descriptive Statistical Analysis on the Women Livelihood Security Variables}

The primary data obtained from 140 sample women agricultural labourer households selected from4revenue villages of Erode District in Tamil Nadu were utilized for analysis. A simple descriptive statistical analysis based on mean, median, standard deviation, minimum and maximum were performed to work out the mean statistics of the variables included in the study. Proxies were used in the study for certain variables on the basis of scaling as detailed in the data description. The results of the descriptive statistics performed in the study presented in table-II showed the mean statistics of different livelihood security variables included in the study. 
TABLE-II: DESCRIPTIVE STATISTICAL ANALYSIS ON THE WOMEN LIVELIHOOD SECURITY VARIABLES

\begin{tabular}{|c|c|c|c|c|c|}
\hline Variables & 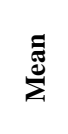 & 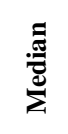 & 这 & 志 & $\underset{\sum}{\stackrel{\Xi}{\Xi}}$ \\
\hline Economic Security Index & 0.61 & 0.51 & 0.39 & $\begin{array}{c}0.1 \\
0\end{array}$ & 0.93 \\
\hline Food Security Index & 0.54 & 0.51 & 0.35 & $\begin{array}{c}0.2 \\
7\end{array}$ & 0.93 \\
\hline Health Security Index & 0.70 & 0.68 & 0.43 & $\begin{array}{c}0.3 \\
0\end{array}$ & 1.10 \\
\hline Education Security Index & 0.70 & 0.68 & 0.44 & $\begin{array}{c}0.2 \\
7\end{array}$ & 1.10 \\
\hline Empowerment Index & 0.72 & 0.68 & 0.43 & $\begin{array}{c}0.1 \\
0\end{array}$ & 1.10 \\
\hline $\begin{array}{l}\text { Cumulative Livelihood } \\
\text { Security Index (CLSI) }\end{array}$ & 0.65 & 0.65 & 0.30 & $\begin{array}{c}0.2 \\
8\end{array}$ & 0.91 \\
\hline Family type [FAMILY] & 1.44 & 1.18 & 0.62 & 1 & 2 \\
\hline $\begin{array}{l}\text { Number of Household } \\
\text { Member [NOHM] }\end{array}$ & 4.14 & 4.18 & 1.67 & 1 & 11 \\
\hline $\begin{array}{l}\text { Age of the respondent } \\
\text { [AGER] }\end{array}$ & $\begin{array}{c}40.6 \\
9\end{array}$ & $\begin{array}{c}39.1 \\
8\end{array}$ & $\begin{array}{c}10.7 \\
4\end{array}$ & 29 & 65 \\
\hline $\begin{array}{l}\text { Age difference between } \\
\text { spouses [ADBS] }\end{array}$ & 4.89 & 5.18 & 3.02 & 1 & 9 \\
\hline $\begin{array}{l}\text { No. of children in a family } \\
{[\mathrm{NOCF}]}\end{array}$ & 2.10 & 2.18 & 1.53 & 1 & 6 \\
\hline Educational status [REDL] & 4.55 & 4.68 & 4.56 & 0 & 12 \\
\hline $\begin{array}{l}\text { Educational difference with } \\
\text { spouse [EDWS] }\end{array}$ & 1.39 & 0.18 & 4.21 & -8 & 19 \\
\hline Dependency ratio [DEPR] & 0.74 & 0.78 & 0.43 & 0 & 1 \\
\hline Access to Assets [ASSET] & 0.42 & 0.18 & 0.61 & 0 & 1 \\
\hline $\begin{array}{l}\text { Access to media and } \\
\text { communication [MEDIA] }\end{array}$ & 0.77 & 1.18 & 0.67 & 0 & 1 \\
\hline $\begin{array}{l}\text { Access to Community / } \\
\text { Political participation [POLT }\end{array}$ & 0.39 & 0.18 & 0.67 & 0 & 1 \\
\hline $\begin{array}{l}\text { Log percapita income of the } \\
\text { household [LOG-PINH] }\end{array}$ & 9.95 & 9.90 & 2.23 & $\begin{array}{c}2.6 \\
8\end{array}$ & $\begin{array}{c}13.7 \\
8\end{array}$ \\
\hline
\end{tabular}

From the analysis that the total sample women agricultural labourer households (140) selected for the study, on an average only 38 percent of the households were joint families; while 62 percent were nuclear types. The average size of the family relating to the composite data was worked out to be 4.14 and varies between the minimum of 1 to the maximum of 11 . The average age of the women agricultural workers for the data was 40.69 years and the average number of children below the age 6 years in a family of the selected households in the district was 1 ; lies between 29 and 65 years; while the mean age for their spouses was 45.48 years and ranges between 30 and 74 years. The mean age difference between the respondents and spouse was about 9 years. The average years of schooling by the women agricultural labour households was 4.55 years while it was 5.89 years for their spouses. The average educational difference between the respondents and their spouse was less than 1.39 years. The dependency ratio of the households selected for the study was worked out to be 0.74 percent in the district indicating the fact that majority of the family members in a household selected for the study were deemed to be the dependents, either in the form of children and or adults aged. On an average, 42 percent of the women respondents selected for the study have ownership access to household immovable assets. The percentage of women respondents who had political access to decision making was worked out to 39 percent indicating the fact that political awareness to the households in rural areas in
Erode district was dissemble. It was also seen from the estimates that the mean logarithmic value of the per-capita income worked out for the women households selected for the study was 9.95 percent and ranged between the minimum of 2.68 to the maximum of 13.78 .

C. The Determinants of Livelihood Security of Women Agricultural Labourers and their Implications on the Status of Women

This part of the study deals with the significant determinants of livelihood security of women agricultural labourers in Erode district of Tamil Nadu based on the primary data collected from 140 women respondents selected for this purpose. Multiple Regression equation method was fitted to the data to explore the effects of the explanatory variables on livelihood security of women agricultural labourers. Thus, the dependent variable in the multiple regression analysis is the quantitative variable viz., Economic Security Index, Food Security Index, Health Security Index, Education Security Index, Empowerment Index and Cumulative Livelihood Security Index (CLSI), and the various explanatory variables that affect the level of livelihood security among agricultural labourer women in the district. The estimated results of the regression coefficients using the multiple regression models pertaining to the livelihood security variables included are presented in table-III.

\section{TABLE-III: ESTIMATED RESULTS OF THE EXPLANATORY VARIABLES IN THE MULTIPLE REGRESSION ANALYSIS}

\begin{tabular}{|c|c|c|c|c|c|c|}
\hline 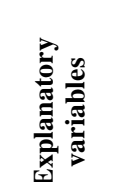 & 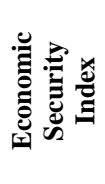 & 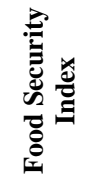 & 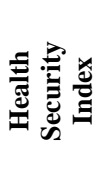 & 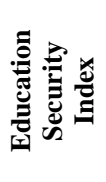 & 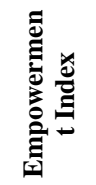 & 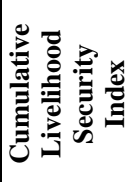 \\
\hline & $\boldsymbol{\beta}$ & $\beta$ & $\beta$ & $\beta$ & $\beta$ & $\beta$ \\
\hline Constant & $\begin{array}{c}0.426 \\
(4.770)\end{array}$ & $\begin{array}{c}0.425 \\
(5.920)\end{array}$ & $\begin{array}{c}0.676 \\
(7.051)\end{array}$ & $\begin{array}{c}0.505 \\
(4.820)\end{array}$ & $\begin{array}{c}0.664 \\
(6.906)\end{array}$ & $\begin{array}{c}0.539 \\
(11.099)\end{array}$ \\
\hline FAMLY & $\begin{array}{l}0.111 * \\
(5.144)\end{array}$ & $\begin{array}{l}0.047 * \\
(2.766)\end{array}$ & $\begin{array}{c}-0.034 \\
(-0.176 \\
)\end{array}$ & $\begin{array}{c}0.012 \\
(0.358)\end{array}$ & $\begin{array}{l}0.113 * \\
(4.561)\end{array}$ & $\begin{array}{l}0.035^{* *} * \\
(2.330)\end{array}$ \\
\hline NOHM & $\begin{array}{c}-0.101 \\
(-0.385 \\
)\end{array}$ & $\begin{array}{c}-0.118 * \\
(-7.966 \\
)\end{array}$ & $\begin{array}{c}0.025 * \\
(-3.224 \\
)\end{array}$ & $\begin{array}{l}-0.037 \\
(4.724)\end{array}$ & $\begin{array}{c}-0.043 * \\
(-2.099 \\
)\end{array}$ & $\begin{array}{l}-0.013 * \\
(-3.349) \\
\end{array}$ \\
\hline AGER & $\begin{array}{c}0.038^{*} \\
* \\
(1.909) \\
\end{array}$ & $\begin{array}{l}0.026 * \\
(2.281) \\
\end{array}$ & $\begin{array}{c}-0.100 \\
(-1.099 \\
(\end{array}$ & $\begin{array}{l}0.021 * \\
(2.008) \\
\end{array}$ & $\begin{array}{l}0.034 * \\
(3.766) \\
\end{array}$ & $\begin{array}{l}0.027 * \\
(2.526)\end{array}$ \\
\hline ADBS & $\begin{array}{c}0.101 \\
(0.766)\end{array}$ & $\begin{array}{r}0.118 \\
(2.460)\end{array}$ & $\begin{array}{c}-0.016 * \\
(-4.099 \\
)\end{array}$ & $\begin{array}{c}-0.005^{*} \\
* \\
(-1.349) \\
\end{array}$ & $\begin{array}{c}0.100 \\
(0.349)\end{array}$ & $\begin{array}{l}0.102 \\
(1.599)\end{array}$ \\
\hline NOCF & $\begin{array}{c}-0.024 * \\
(-3.528 \\
)\end{array}$ & $\begin{array}{c}-0.027 * \\
(-4.599 \\
)\end{array}$ & $\begin{array}{c}0.116 \\
(1.988( \\
\end{array}$ & $\begin{array}{c}0.110 \\
(1.321) \\
\end{array}$ & $\begin{array}{c}-0.023 * \\
(-2.655 \\
)\end{array}$ & $\begin{array}{c}-0.009 * \\
* \\
(-2.349) \\
\end{array}$ \\
\hline REDL & $\begin{array}{l}0.041 * \\
(2.682) \\
\end{array}$ & $\begin{array}{l}0.021 * \\
(5.599) \\
\end{array}$ & $\begin{array}{l}0.018 * \\
(4.432) \\
\end{array}$ & $\begin{array}{l}0.017 * \\
(3.766) \\
\end{array}$ & $\begin{array}{l}0.042 * \\
(4.099) \\
\end{array}$ & $\begin{array}{c}0.049 * * \\
(1.956)\end{array}$ \\
\hline EDWS & $\begin{array}{c}0.100 \\
(0.599) \\
\end{array}$ & $\begin{array}{c}0.100 \\
(0.599) \\
\end{array}$ & $\begin{array}{c}0.101 \\
(0.766) \\
\end{array}$ & $\begin{array}{l}0.013 * \\
(4.432) \\
\end{array}$ & $\begin{array}{l}0.027 * \\
(2.176) \\
\end{array}$ & $\begin{array}{c}0.011 \text { ** } \\
(1.932)\end{array}$ \\
\hline DEPR & $\begin{array}{c}0.148 \\
(1.460)\end{array}$ & $\begin{array}{c}-0.065 * \\
(-2.340 \\
)\end{array}$ & $\begin{array}{c}0.130 \\
(0.820)\end{array}$ & $\begin{array}{c}0.135 \\
(0.899)\end{array}$ & $\begin{array}{c}-0.093 * \\
(-2.262 \\
)\end{array}$ & $\begin{array}{c}-0.045^{*} \\
* \\
(-2.242)\end{array}$ \\
\hline
\end{tabular}




\begin{tabular}{|c|c|c|c|c|c|c|}
\hline ASSET & $\begin{array}{l}0.145 * \\
(7.004)\end{array}$ & $\begin{array}{l}0.054 * \\
(3.275)\end{array}$ & $\begin{array}{c}-0.139 \\
(-1.699 \\
)\end{array}$ & $\begin{array}{l}0.079 * \\
(3.259)\end{array}$ & $\begin{array}{l}0.047 * \\
(2.016)\end{array}$ & $\begin{array}{c}0.030 * * \\
(2.599)\end{array}$ \\
\hline MEDIA & $\begin{array}{c}-0.106 \\
(-0.488 \\
)\end{array}$ & $\begin{array}{c}0.118 \\
(1.366)\end{array}$ & $\begin{array}{l}0.092^{*} \\
(4.480)\end{array}$ & $\begin{array}{c}-0.105 \\
(-0.372)\end{array}$ & $\begin{array}{c}0.105 \\
(0.385)\end{array}$ & $\begin{array}{c}0.101 \\
(0.299)\end{array}$ \\
\hline POLT & $\begin{array}{c}-0.109 \\
(-0.655 \\
) \\
\end{array}$ & $\begin{array}{c}-0.103 \\
(-0.366 \\
)\end{array}$ & $\begin{array}{l}0.043^{*} \\
(2.054)\end{array}$ & $\begin{array}{l}0.044 * * \\
(2.012)\end{array}$ & $\begin{array}{c}0.115 \\
(0.826)\end{array}$ & $\begin{array}{c}0.100 \\
(0.190)\end{array}$ \\
\hline $\begin{array}{c}\text { LOG-PIN } \\
\text { H }\end{array}$ & $\begin{array}{l}0.016^{*} \\
(3.699) \\
\end{array}$ & $\begin{array}{l}0.034 * \\
(3.099) \\
\end{array}$ & $\begin{array}{l}0.025^{*} \\
(5.766) \\
\end{array}$ & $\begin{array}{l}0.046^{*} \\
(2.766) \\
\end{array}$ & $\begin{array}{l}0.057^{*} \\
(4.882) \\
\end{array}$ & $\begin{array}{l}0.012 * * \\
(2.432) \\
\end{array}$ \\
\hline $\mathrm{R}$ & 0.807 & 0.844 & 0.754 & 0.763 & 0.893 & 0.728 \\
\hline $\mathrm{R}^{2}$ & 0.778 & 0.818 & 0.711 & 0.741 & 0.846 & 0.710 \\
\hline $\begin{array}{c}\text { Adjusted } \\
\mathrm{R}^{2} \\
\end{array}$ & 0.770 & 0.811 & 0.702 & 0.732 & 0.839 & 0.701 \\
\hline $\mathrm{F}$ & 3.066 & 4.913 & 2.496 & 3.079 & 3.411 & 3.137 \\
\hline $\mathrm{N}$ & 140 & 140 & 140 & 140 & 140 & 140 \\
\hline
\end{tabular}

* Significant at $1 \%$ level, ** Significant at $5 \%$ level, *** Significant at 10 $\%$ level

The estimated regression co-efficients pertaining to the composite data presented in table-III indicated the fact that the fitted regression equation is statistically significant according to the livelihood security perception made in the study and The $\mathrm{R}^{2}$ values of multiple regression models explained 71 percent variation respectively in livelihood security which is due to the explanatory variables and depicts a moderate goodness of fit. The $\mathrm{F}$ values of the models are highly found significant and indicate that systematic variation in the livelihood security variables are considerably larger. The positive signs registered for the explanatory variables namely family type, age, education, educational difference between spouse, access to ownership of assets, access to media and communication, access to political participation and log percapita income are those factors whose impact might make guidance and direct the policy makers and the institutions involved in the livelihood security process to enhance the women livelihood security programmes across the country.

The negative signs registered for the explanatory variables viz., number of household members, number of children in a family and dependency ratio have indicated for negative relationship with livelihood security of women. In other words, according to the livelihood security perception, joint family respondents are lesser would be the livelihood security; more is the family size less is the livelihood security of women as they could not spare adequate time to know things. Greater is the age difference with spouse lesser is the scope for women livelihood security. Similarly, more is the number of children's in a family less is the livelihood security of women. Greater is the educational difference with spouse more is the livelihood security of women. Larger the dependency ratio, more is the amount spent for the household therefore less would be the livelihood security of women.

The positive signs of the estimated regression co-efficient pertaining to the composite data are indicative of the positive relationship of the explanatory variables with composite livelihood security index of agriculture labourer women. In other words, more is the respondents age greater is the livelihood security of women, higher the educational status of the respondents more would be the livelihood security. When the respondent of the households is nuclear more is the scope for livelihood security of women. Similarly, greater is the respondent access to asset ownership and log per-capita income of the household, higher is the livelihood security of women. The results obtained from the study therefore clearly depicts the fact that women livelihood security in rural areas of the one selected for the study has some distinct requirements viz., age maturity, increasing the level of education, ownership access to assets and higher log percapita income.

\section{CONCLUSIONS}

The study was concluded that the standard of living of women engaged in agriculture in rural areas of Erode County is far from satisfactory. Despite the many development programs initiated by the government over the years, the socio-economic institutions that impede the welfare of women in the district continue to play an important role in the slow progress in raising the living standards of women in the districts. Rural women access to income, access to property, political participation, access to education, meeting health needs, decision-making opportunities at the family level, etc. D. D. D. It has not yet been reached by stakeholders. The situation of rural women in these areas is even today considered secondary, and they are not given any importance. Domestic violence, harassment, infanticide among women, beating of wives, divorces, and psychological torture still continue, which has serious cumulative negative consequences for the health and quality of life of women.

Therefore, in order to move towards the goals of women's empowerment initiatives and programs that are active in the country, the study suggests some concrete steps in which all implementing agencies should be involved, namely government organizations, non-governmental organizations, women involved in development Organizations and all other stakeholders and civil society must effectively stimulate the lives of women. Government intervention must be strengthened through legislation, planning and implementation so as to provide greater opportunities for sustainable development, women's livelihood at all levels, so that women's discriminatory practices and gender issues are addressed to women.

\section{REFERENCES}

1. Ganesh Kumar. B, R. Sendhil, P. Venkatesh, R. Raja, V. Jayakumar and S. Jeyakumar, "Socio-economic Impact Assessment of Livelihood Security in Agriculture, Animal Husbandry and Aquaculture on the Tsunami-hit Lands of Andaman, Agricultural Economics Research Review, Vol. 22 (Conference Number) 2009, pp. 483-494

2. Sanzidur Rahman and ShaheenAkter, "Determinants of Livelihood Security in Poor Settlements in Bangladesh", NAF-International Working Paper Series, Paper n. 10/01, Year 2010, available at http://economia.unipv.it/naf/

3. Marc Lindenberg, "Measuring Household Livelihood Security at the Family and Community Level in the Developing World", World Development Vol. 30, No. 2, pp. 301-318, 2012.W

4. Dhanasree. K, and B.Vijayabhinandana, "Livelihood Security of Tribal Women in High Altitude and Tribal Zone of Andhra Pradesh", International Journal of Extension Education, Vol.9, pp. 47-50, 2013.

5. YishakGecho, GezahegnAyele, Tesfaye Lemma1, DawitAlemu, "Rural household livelihood strategies: Options and determinants in the case of Wolaita Zone, Southern Ethiopia”, Social Sciences, 2014; 3(3): 92-104

6. Hahn M B, Riederer A M \& Foster S O 2009. The Livelihood Vulnerability Index: A Pragmatic Approach to Assessing Risks from Climate Variability and Change-A Case Study in Mozambique, Global Environmental Change, 19(1): 74-88.

7. Hahn M B, Riederer A M \& Foster S O 2009. The Livelihood Vulnerability Index: A Pragmatic Approach to Assessing Risks from Climate Variability and Change-A Case Study in Mozambique, Global Environmental Change, 19(1): 74-88. 


\section{AUTHORS PROFILE}

Dr.G.Ramesh Pandi M.Com, M.Phil., Ph.D, SET, PGDCA, PGDPM. Author has published more than twenty two articles in the National and International level journals. One article published in the Scopus indexed journal. He is a member of Teaching and Education Research Association (TERA) and Social Science Research Association (SSHRA) of Eurasia Research. He has received Teaching Competency Award from Kalasalingam Academy of Research and Education (Deemed to be University), Virudhunagar District of Tamilnadu. He has presented sixty one papers in the national and international level seminars and Conference organized by various Institutions. He has cleared three NPTEL courses. He acted as a chair person for various seminars, conferences and workshops.

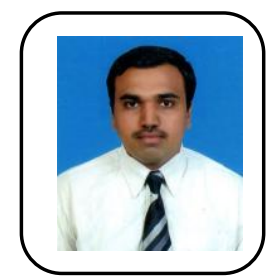

Dr.S.B.Inayath Ahamed is working as Assistant Professor in Kalasalingam Business School. He had completed his B.E (EEE) from Sona College of Technology, Salem and he did his M.B.A from Crescent Business School, Chennai.He did his research in Periyar Institute of Management Studies, Periyar University, and Salem on Dairy Supply Chain. He had cleared UGC NET and SET in the year 2012 he was Senior Research Fellow at PRIMS for a year. He has 4 years of Research Experience and 3 Years of Academic Experience. He had published many scholarly papers in reputed Journals.

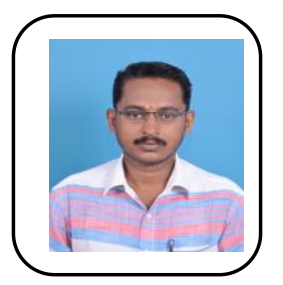

Prof.Dr.A.Saravanan, M.A., M.Phil., Ph.D., working as Assistant Professor of Economics, J.K.K.Nataraja College of Arts \& Science, Komarapalayam, Namakkal District, Tamil Nadu. He did Ph.D., in Economics under the guidance of Prof.Dr.A.Raja, M.A., M.Phil., Ph.D., D.Litt., a distinguished Professor of Economics, Gobi Arts \& Science College, Gobichettipalayam, Tamil Nadu. The author has 10 years of experience in the field of teaching, research and analytical areas of research theme. He has completed 1 UGC Minor Research Project on "Educational Deprivation of Malaiyali Tribal Women in Namakkal District of Tamil Nadu" during 2015-2016. He has published 19 articles and participated in 49 conference, seminars and workshop in the national and state level. In addition to he has experience in organizing national level conference and seminars. He has a unique expertise in the analyzing the data by using SPSS, STATA, etc in unmatched manure with others. 